\title{
Okul Öncesi Dönemde Risperidon ve Metilfenidat Tedavisi Başlanan Hastaların İlaç Tedavisinden Fayda Görmeleri ve Yan Etkiler Açısından Retrospektif Taranması
}

\author{
Retrospective Analysis of Risperidone and Methylphenidate Use in \\ Preschool Age According to the Drug Benefit and Side Effects \\ Dilek ÜNAL, Kevser NALBANT, Ekin GÜNAL, Mine AYBI
}

Hacettepe Üniversitesi, Tıp Fakültesi, Çocuk ve Ergen Ruh Sağlı̆̆ı Anabilim Dalı, Ankara, Türkiye

\section{öz}

Amaç: Okul öncesi yaș grubundaki çocuklarda psikiyatrik bozukluklar için giderek artan düzeyde ilaç tedavisi uygulanmasına rağmen, bu yaş grubundaki çocuklarda psikiyatrik ilaç yararlanımına, ilaç yan etkilerine ilişkin yeterli sayıda araștıma yoktur. Çalıșmamızda bu yaș grubunda kliniğimizde değerlendirilen hastaların kayıtlarının, en sık kullanılan metilfenidat ve risperidon ilaç tedavilerinin yararlanımları, dozları, yan etkileri ve tedaviye yanıt üzerinde etkisi olabileceği düşünülen eşlik eden özellikler açısından araştıııması hedeflenmiştir.

Gereç ve Yöntemler: Bu amaçla, kliniğimizde 0-6 yaș aralığındaki ilaç tedavisi başlanan hastaların retrospektif muayane kayıtları incelenmiștir. 45 risperidon ve 50 metilfenidat kullanan hastanın ilaç yararlanımı, Klinik Global İzlenim (KGi) ve Global Değerlendirme Ölçeği (GDÖ) ölçekleri skorlanarak belirlenmiştir. Risperidon ve metilfenidat kullanan hastalar araştırılan parametreler açııından kendi grupları içinde ve her iki grup biribiriyle karşılaştııılmıştır.

Bulgular: Risperidon ve metilfenidat kullanan hastaların ilaç tedavisi öncesi ve sonrası değerlendirmeleri arasında semptom şiddeti (KGi-Ş skorlarındaki azalma) ve işlevsellik düzeyi (GDÖ skorlarındaki artış) açısından anlamlı düzelme bulunmuştur. Her iki grupta tedaviye yanıt üzerinde etkisi olabileceği düşünülen eșlik eden yaş, cinsiyet, okul öncesi eğitim alma, prenatal-natal-postnatal sorun, tıbbi hastalık gibi etkenlerin ilaçtan yararlanım ve yan etki açısından anlamlı bir ilişki bulunmamıştır.

Sonuç: Okul öncesi yaş grubunda davranış sorunları, hiperaktivite, irritabilite tedavisi için önerilen ilaç tedavilerinden metilfenidat ve risperidon faydalı ve güvenilir bulunmuştur. Bu yaş grubunda psikofarmakolojik tedaviler ile ilgili daha net sonuçlara ulaşabilmek için, geniş örneklemli ve uzun süre izlem içeren, prospektif çalışmalara intiyaç vardır.

Anahtar Sözcükler: Metilfenidat, Okul öncesi, Risperidon

\begin{abstract}
Objective: Although there is increasing number of psychopharmacological treatments in preschoolers, there is still limited information in literature about the efficacy and safety of the drugs. In this study, we aimed to investigate the efficacy, doses, side effects and the variables that predict the clinical benefit of the most used drugs(methylphenidate and risperidone) in our clinic from preschoolers.
\end{abstract}

Material and Methods: The patient records in our clinic, whose medication was started between 0-6 years old were scanned retrospectively. Fifty children using methylphenidate and 45 children using risperidone were evaluated with

(1)

: 0000-0002-5125-9923 :0000-0003-4261-1013

GÜNAL E : :0000-0003-3595-6689

AYBI M : :0000-0001-7654-1637
Çıkar Çatışması / Conflict of Interest: On behalf of all authors, the corresponding author states that there is no conflict of interest.

Etik Kurul Onayı / Ethics Committee Approval: Çalıșma için Hacettepe Üniversitesi, Girișimsel Olmayan Klinik Araștırmalar Etik Kurulu'ndan 2019/15-1611.06.2019 tarihli onay alınmıştır.

Yazarların katkısı / Contribution of the Authors: ÜNAL D: Araştırma ve/veya makalenin hipotezini veya fikrini oluşturan, Sonuçlara ulaşmak için planlama/ metodoloji belirleme, Araștırma/çalıșmanın sorumluluğunu üstlenmek, ilerlemenin seyrini denetlemek, Sonuçların mantıksal olarak Yorumlanması ve sonuçlandırıması, Çalıșma için gerekli literatür taramasında sorumluluk almak, Çalıșmanın bütününün veya önemli bölümlerinin yazımında sorumluluk almak. NALBANT K: Araștırma/ çalıșmanın sorumluluğunu üstlenmek, ilerlemenin seyrini denetlemek, Sonuçların mantıksal olarak Yorumlanması ve sonuçlandırıması, Yazım ve dilbilgisi dıșında bilimsel olarak gönderilmeden önce makaleyi gözden geçirme. GÜNAL E: Hasta takibinde sorumluluk almak, ilgili biyolojik malzemelerin toplanması, veri yönetimi ve raporlama, deneylerin yürütülmesi, Çalıșma için gerekli literatür taramasında sorumluluk almak. AYBI M: Hasta takibinde sorumluluk almak, ilgili biyolojik malzemelerin toplanması, veri yönetimi ve raporlama, deneylerin yürütülmesi, Çalışma için gerekli literatür taramasında sorumluluk almak.

Atıf yazım şekli / How to cite : Ünal D, Nalbant K, Günal E,Aybı M. Okul Öncesi Dönemde Risperidon ve Metilfenidat Tedavisi Bașlanan Hastaların llaç Tedavisinden Fayda Görmeleri ve Yan Etkiler Açısından Retrospektif Taranması. Turkish J Pediatr Dis 2021;15:299-305. 
scored Clinical Global Impression Scale (CGI) and Global Assessment of Functioning Scale (GAS). Patients using methylphenidate and risperidone were compared in their own group and with each other concerning the parameters investigated.

Results: There was a statistifically significant difference between before and after drug assessments of the patients according to symptom severity(CGI-S scores) and clinical functionality (GAS scores). The age, gender, presence of preschool education, prenatalnatal-postnatal problem or medical disease history had no significant relationship with the efficacy or side effects of the drugs. None of the medication investigated were found superior to other concerning the efficacy and side effect profiles.

Conclusion: Methylphenidate and risperidone were found effective and safe among the drugs recommended for the pharmacological treatment of behaviour problems, hyperactivity and irritability in the preschool age. Further prospective studies in larger clinical samples with longer follow-up periods are needed to draw certain conclusions about the psychopharmacological treatments in preschoolers.

Key Words: Preschool, Methylphenidate, Risperidone

\section{Giriş}

Okul öncesi çağda psikiyatrik belirtiler nedeniyle kliniklere başvurular geçmişe göre oldukça sık görülmektedir (1-3). DSM-IV (Ruhsal Bozuklukların Tanısal ve Sayımsal El Kitabı) tanı kriterleri baz alınarak yapılan epidemiyolojik çalışmalarda bu yaş grubunda psikiyatrik bozukluklar için \%12 gibi bir insidans saptanmıştır $(4,5)$.

Bu yaş grubundaki ruhsal bozuklukların tedavisinde psikososyal yaklaşımlar ve davranış terapileri öncelikli olarak önerilse de, bu hizmetlere ulaşım kısıtılığı, değerlendirilmesi gereken hasta çokluğu gibi nedenler ile ilaç tedavilerinin kullanımı son 20 yılda artış göstermiştir (6). Buna rağmen, günümüzde halen okul öncesi yaş grubundaki ilaç kullanımına ilişkin kısıtlı sayıda randomize kontrollü ilaç çalışmaları vardır (7).

Nörogelişimsel bozukluklar için ABD de yapılan bir araştırmada 2-17 yașarasındaki çocuklarda \%15 gibi bir insidansa ulaşılmıştır ve bunlar içinde en sık Dikkat eksikliği hiperaktivite bozukluğu (DEHB) görülmektedir. Özgül öğrenme bozukluğunun (ÖÖB) örgün eğitimle birlikte tanı aldığı düşünüldüğünde, okul öncesi çağda en sık tanı alan diğer bozukluklar da Otizm spektrum bozukluğu (OSB) ve bilişsel yetersizliktir (BY). Tüm dünyada en sık psikiyatrik hastalıkların biri olan DEHB okul öncesi çağda 1. basamak kliniklerde \%2'nin altında görülürken, çocuk psikiyatrisi kliniklerinde bu oran \%59'un üzerine çıkmaktadır (8). Bu bozukluklar sıklıkla bir arada görülebilmektedir (9). DEHB için sıklıkla ilaç tedavisi önerildiği gibi, OSB ve BY'de bozukluğa komorbid DEHB ve/veya ortaya çıkan davranış sorunları (agresyon, kendine zarar verme, yoğun stereotipi gibi belirtiler) için de ilaç tedavileri kullanılmaktadır.

Okul öncesi psikofarmakoloji çalışma grubu önerisine göre, okul öncesi DEHB tanılı olgularda metilfenidat birinci basamak psikofarmakolojik ajandır. Ancak, okul öncesi DEHB tedavisi ile ilgili geniş örneklemli bir çalışmada, okul öncesi çocuklarda metilfenidatın etki gücü okul çağı çocuklara göre daha az bulunmuştur (10). Okul öncesi grupta ek olarak labilite, sinirlilik, irritabilite, ağlamaya meyil gibi duygusal yan etkiler daha sık gözlenmektedir (11).

Okul öncesi çağda DEHB tanısı konmuş 33 çocuğun risperidon ve metilfenidat kullanımının karşılaştııılığı bir çift kör randomize çalışmada, uygulanan ölçeklere göre 2 grupta DEHB ilişkili davranış sorunları açısından anlamlı fark bulunmamıştır.
Risperidonun görece daha iyi tolere edildiği belirtilmiştir (1). DEHB tanısı almış 3-6 yaş arası 42 okul öncesi çocukla yapılan bir araştırmada, yalnızca metilfenidat kullanımı ile kombine risperidon ve metilfenidat kullanımı karşılaştırılmıştır. Conners Ebeveyn Derecelendirme Ölçeği'ne göre iki grup arasında anlamlı fark bulunmuş, risperidon ile metilfenidatın kombine kullanıldı̆̆ı grupta metilfenidat dozları daha düşük kullanılabildiği için metilfenidata bağı yan etkiler (uykusuzluk, iştahsızlık, vb.) daha az görülmüştür (12). Yakın zamanda, risperidonun ülkemizde bu yaş grubunda klinik örneklemde en sık kullanılan psikiyatrik ilaç olduğu, ve bu yaş grubunda yıkıcı davranış sorunları üzerinde etkin ve güvenilir olduğu gösterilmiştir $(3,13)$.

Risperidon OSB' deki davranış problemlerinde tercih edilebilecek bir ajandır $(14,15)$. DSM-IV'e göre yaygın gelişimsel bozukluk tanısı konulmuş, ortalama yaşları 4-7 arasında olan 10 çocukta, risperidon tedavisinin klinik değerlendirmesinin yapıldığı bir çalışmada 16 hafta sonunda Çocukluk Çağı Otizmi Puanlama Ölçeği (Childhood Autism Rating Scale, CARS), Klinik Global İzlem Ölçeği (KGi), psikiyatrik belirti derecelendirme ölçekleri skorlarında anlamlı derecede iyileşme gözlenmiştir. İzlem boyunca taşikardi, yüzde kıarma, yüksek ateş, yorgunluk gibi yan etkiler gözlenmiştir (16).

Okul öncesi çağdaki çocuklarda psikiyatrik ilaç kullanımı, etkinliği ve yan etki profili açısından yapılan çalışmaların konuyu aydınlatma açısından yeterli olmadığı, konuyla ilgili klinik pratiğe katkı sağlayacak yeni çalışmalara intiyaç olduğu düşünülmüştür. Buradan yola çıkılarak planlanan araştırmamızda, kliniğimizdeki uygulama ve sonuçların anlaşılabilmesi için, Ocak 2014Ocak 2016 tarihleri arasında bölümümüze bașvuran, 0-6 yaș aralığındaki DEHB, OSB, BY tanısı konmuș hastalara bașlanan risperidon ve metilfenidatın etki ve yan etkileri ile bu ilaçlardan fayda görmeyi yordayan etkenlerin, eşlik eden klinik özelliklerin geriye dönük olarak incelenmesi hedeflenmiștir.

\section{GEREÇ ve YÖNTEMLER}

Ocak2014- Ocak 2016 tarihleriarasında bölümümüze başvuran, 0-6 yaș aralığındaki DEHB, OSB, BY tanısı konmuș hastaların muayene kayıtları hastane otomasyon sisteminden retrospektif olarak taranmıştır. İlaç tedavisi başlanan 257 hastanın kaydına ulaşılmıştır. Bu hastaların 149'una metilfenidat veya risperidon ilaç tedavisi başlanmış olduğu görülüp, bunlardan araştırmaya 
dahil edilme kriterlerine uyan 45 risperidon kullanan, 50 metilfenidat kullanan hasta kaydına ulaşılmıştır. Hastaların ilaç yararlanımı, Klinik Global İzlenim (KGi) ve Global Değerlendirme Ölçeği (GDÖ) Ölçekleri kullanılarak, klinisyenlerin muayene notlarına göre dosya taramasını yapan araştırmacılar tarafından skorlanarak belirlenmiştir. İlaç tedavisi planı sonrası reçete edilen ilacı kullanarak geldikleri 1. ve 6. Ayda kontrollerinde, skorlama için klinik notları yeterli, risperidon ilaç tedavisi alan 50 çocuk ile metilfenidat ilaç tedavisi alan 45 çocuk, tanıları, sosyodemografik verileri, kullandıkları ilaç dozları, yan etkiler, ilaç tedavisinden fayda görmeleri ve ilaç tedavisinden fayda görmeyi etkileyebileceği düşünülen değişkenler açısından incelenmiştir. Metilfenidat alanlarda ajitasyon, risperidon alanlarda enurezis ve ajitasyon ilaç kesme nedeni olarak kabul edilmiştir.

Çalışma için Hacettepe Üniversitesi, Girişimsel Olmayan Klinik Araştırmalar Etik Kurulu'ndan 2019/15-16- 11.06.2019 tarihli onay alınmıştır.

Demografik-Klinik Veri Formu : Çalışmaya dahil edilen hastaların sosyo-demografik özellikleri, gelişimsel ve psikiyatrik öyküleri hasta kayıtlarından alınmıştır. Sosyoekonomik düzey Hollinghead Redlich ölçeğine göre belirlenmiştir.

Hollingshead-Redlich Ölçeği : Anne ve babanın meslek ve eğitim durumlarını esas alarak, belirli bir süre için ulaşılmış en üst düzeyi yansıtan genel bir ölçüm yapar. Ölçekte beş ayrı sosyoekonomik-sosyokültürel düzey (SED) tanımlanmıştır, 1 en yüksek, 5 en düşük sosyoekonomik düzeyi tanımlamaktadır (17).

Klinik Global İzlenim Öıçeği (KGI): Ulusal Ruh Sağlığı Enstitüsü(NIMH) 'nün sponsorluğundaki klinik denemelerinde kullanılmak amacıla, hastaların tedavi öncesi ve sonrası işlevselliğini kısaca tarayabilmek için oluşturulmuştur (18). Klinik Global İlenim Ölçeği, hastanın hikayesi, psikososyal çevresi, semptomları, davranışları ve semptomların işlevselliğine etkisi hakkında klinisyen temelli özet bir ölçüm sunar (19). Klinik Global İzlenim Ölçeği'nin hastalık şiddeti ( KGI-Ş), ilaç yan etkisi ( KGI-YE), düzelme ( KGI-D) alt ölçekleri mevcuttur. Buna göre hastanın klinik durumu, tedavi öncesi ve sonrasında skorlanabilir.

Global Değerlendirme Ölçeği(GDÖ): Psikiyatrikhastalıklardan, sağlığa uzanan spektrumda, bireyin işlevselliğini belli bir zaman periyodu içerisinde değerlendiren bir ölçektir. Ölçek 1'den 100'e kadar puanlanmıştır. 1 hipotetik olarak en hasta bireyi temsil ederken, 100 hipotetik olarak en sağlıkı bireyi temsil etmektedir (20).

\section{İstatistiksel Analiz:}

Sosyal Bilimler İçin İstatistik Paket Programı (Statistical Program for Social Sciences, SPSS) 23.0 sürümü ile yapılmıştır. Ölçümle belirtilen verilerin değerlendirilmesinde; parametrik test varsayımları karşılandığında paired ve independent sample t-testi, sayımla belirtilen verilerin gruplar arası karşılaştırılmasında ki-kare testi uygulanmıştır. Gruplarda ölçümle belirtilen iki değer arasındaki ilişkiyi araştırmak amacıyla Pearson korelasyon testi kullanılmıştır. Tüm analizlerde p değerinin 0.05'ten küçük olması istatistiksel olarak anlamlı kabul edilmiştir.

\section{BULGULAR}

\section{Risperidon Grubu İçindeki Analizlere Ait Bulgular:}

Risperidon kullanan hastaların 1. (ilaç öncesi) ve 2. (ilaç sonrası ilk değerlendirme) ile 2. (ilaç sonrası ilk değerlendirme) ve 3. (ilaç sonrası 2.değerlendirme) arasında semptom şiddeti azalması (KGi-Ş skorlarındaki azalma) ve işlevsellik düzelmesi (GDÖ skorlarındaki artış) açısından istatistiksel olarak anlamlı fark vardır $(p<0.01)$. Klinik global izlenim düzelme (KGI-D) ve yan etki skorları (KGi-YE) skorları açısından 2. ve 3. değerlendirmeler arasında anlamlı fark bulunmamıştır ( $p>0,5)$. 1. ve 2. değerlendirmedeki risperidon dozları arasında (ikinci değerlendirmedeki risperidon dozu daha yüksek olmak üzere) anlamlı bir fark vardır $(\mathrm{p}=0.001)$.

Risperidon dozu ile 1. ve 2. değerlendirmedeki KGi-Ş, KGI-D, KGI-YE skorları, GDÖ skorları arasında anlamlı bir ilişki bulunamamıştır (P>0.05). İlaç öncesi KGI-Ş skorlarındaki yükseklik BY tanısıyla pozitif yönde ilişkili bulunmuştur $(p<0.01)$. Risperidon kullanan hasta grubunda artan işlevsellik (2. GDÖ skoru ile) ile BY tanısı negatif yönde ilişkili bulunmuştur $(p<0.01)$.

Yapılan korelasyon analizinde, yaş, cinsiyet, okul öncesi eğitim alma, prematürite, prenatal- natal-postnatal sorun olup olmaması, tıbbi hastalık olup olmaması etkenlerinin ilaç sonrası işlevsellik düzeyi (2. GDÖ skoru) ve yan etki skorlarıla ilişkisi bulunmamıştır.

Risperidon ilaç tedavisi başlanan 45 hastadan sadece 9 (\%22.5) hastada yan etki gözlenmiştir. 2 hastanın ilaç tedavisi tedavi sonrası başlayan enürezis nedeniyle ve 1 hastanın ilaç tedavisi de tedavi sonrası gelişen ajitasyon nedeniyle kesilmiştir. Bu hastaların ilaç tedavisi aripiprazol olarak değiştirilmiştir. Görülen yan etkilere ait dağılım Tablo l'de özetlenmiştir.

Tablo I: Metilfenidat ve Risperidon Grubunda Yan Etkilerin Dağılımı.

\begin{tabular}{lc}
\hline & $\mathrm{n}(\%)$ \\
\hline Metilfenidat & $5(10)$ \\
Ajitasyon & $4(8)$ \\
İştahsılık & $3(6)$ \\
Duygusal labilite & $2(4)$ \\
Döküntü & $2(4)$ \\
Baş Ağrısı & $1(2)$ \\
Sersemlik & \\
Risperidon & $4(10)$ \\
Kilo alımı & $2(5)$ \\
Enurezis & $1(2.5)$ \\
Ajitasyon & $2(5)$ \\
Uykululuk &
\end{tabular}


Tablo II: Risperion ve Metilfenidat Gruplarının Klinik Özelliklerinin Karşılaştıııması.

\begin{tabular}{|c|c|c|c|}
\hline & Risperidon (n: 45) & Metilfenidat (n: 50) & p \\
\hline Başvuru yaşı (ort ay $\pm S D$ ) & $48.6( \pm 14.4)$ & $58.6( \pm 10.7)$ & $<0.001$ \\
\hline Cinsiyet $(\mathrm{n} / \%)$ & $\begin{array}{l}\text { K: } 12(\% 26.7) \\
\text { E: } 33(\% 73.3)\end{array}$ & $\begin{array}{l}\text { K: } 3(\% 6) \\
\text { E: } 47(\% 94)\end{array}$ & 0.010 \\
\hline SED & $\begin{array}{r}\text { 1-2 (yüksek)10 (\% 22.2) } \\
3 \text { (orta) } 29 \text { (\%64.4) } \\
45 \text { (düșük) } 6 \text { (\%13.3) }\end{array}$ & $\begin{array}{c}1.2 .17(\% 34) \\
3.22(\% 44) \\
4.5 .11(\% 22)\end{array}$ & 0.058 \\
\hline Prenatal/Perinatal/Postnatal sorun & $\begin{array}{l}\text { Var: } 10(\% 22.2) \\
\text { Yok: } 35(\% 77.8)\end{array}$ & $\begin{array}{l}\text { Var: } 12(\% 24) \\
\text { Yok: } 38(\% 76)\end{array}$ & 1.000 \\
\hline Prematürite öyküsü & $\begin{array}{l}\text { Var: } 4(\% \text { 8.9) } \\
\text { Yok: } 41(\% \text { 91.1) }\end{array}$ & $\begin{array}{l}\text { Var: } 2(\% 4) \\
\text { Yok:48 (\%96) }\end{array}$ & 0.418 \\
\hline Psikiyatrik tanı & $\begin{array}{c}\text { DEHB } 18(\% \text { 40) } \\
\text { OSB } 6(\% 13.3) \\
\text { DEHB+OSB } 21(\% \text { 46.7) }\end{array}$ & $\begin{array}{r}\text { DEHB } 38(\% 75) \\
\text { OSB } 12(\% 25)\end{array}$ & 0.020 \\
\hline BY & $\begin{array}{l}\text { Var: } 20(\% 44.4) \\
\text { Yok: } 25(\% 55.6)\end{array}$ & $\begin{array}{l}\text { Var: } 12(\% 24) \\
\text { Yok: } 38(\% 76)\end{array}$ & 0.041 \\
\hline Tıbbi hastalık & $\begin{array}{c}\text { Var: } 9(\% 20) \\
\text { Yok: } 36(\% 80)\end{array}$ & $\begin{array}{l}\text { Var: } 18(\% 36) \\
\text { Yok: } 32(\% 64)\end{array}$ & 0.054 \\
\hline $\begin{array}{l}\text { Gelişim basamaklarında gecikme } \\
\text { öyküsü }\end{array}$ & $\begin{array}{l}\text { Var } 26(\% 67.2) \\
\text { Yok } 19(\% 32.8)\end{array}$ & $\begin{array}{l}\text { Var } 10(\% 20) \\
\text { Yok } 40(\% 80)\end{array}$ & $<0.001$ \\
\hline Okul öncesi eğitim & $\begin{array}{l}\text { Var: } 31(\% \text { 68.9) } \\
\text { Yok:14 (\% 31.1) }\end{array}$ & $\begin{array}{l}\text { Var: } 49(\% 98) \\
\text { Yok: } 1(\% 2)\end{array}$ & 0.001 \\
\hline Politerapi & 9(\%20)metilfenidat ek & $22(\% 44)$ risperidon ek & $<0.001$ \\
\hline Monoterapi & $36(\% 80)$ & $\begin{array}{l}28(\% 56) \\
37(74 \%) \text { kısa etkili } \\
13(26 \%) \text { uzun etkili }\end{array}$ & 0.001 \\
\hline
\end{tabular}

Tablo III: Risperidon ve Metilfenidat Tedavisine Dair Skorlar, Ilaç Dozları (Ortalama \pm SD).

\begin{tabular}{|l|c|c|}
\hline & Risperidon & Metilfenidat \\
\hline $\begin{array}{l}\text { KGI-Ş 1 (ort } \pm \text { SD) } \\
\text { (Illaçöncesi) }\end{array}$ & $5.31( \pm 0.63)$ & $4.8 \pm 0.8$ \\
\hline GDÖ1 & $39.1( \pm 12.6)$ & $43.4( \pm 8.2)$ \\
\hline İlaç dozu 1 & $0.5( \pm 0.4)$ & $9.11( \pm 6.8)$ \\
\hline KGI-Ş2 & $4.48( \pm 1.07)$ & $4.2 \pm 1.0$ \\
\hline GDÖ2 & $42.8( \pm 14.7)$ & $49.2( \pm 11.3)$ \\
\hline KGI-D2 & $3.45( \pm 0.88)$ & $3.1 \pm 1.1$ \\
\hline KGI-YE2 & $1.33( \pm 0.81)$ & $1.3 \pm 0.7$ \\
\hline İlaç dozu 2 & $0.75( \pm 0.6)$ & $12.7( \pm 6.4)$ \\
\hline KGI-Ş3 & 4.45 & $4 \pm 1$ \\
\hline GDÖ3 & 46.9 & $54( \pm 11.8)$ \\
\hline KGI-D3 & $3.54( \pm 0.80)$ & $3 \pm 0.79$ \\
\hline KGI-YE3 & $1.12( \pm 0.44)$ & $1.5 \pm 1.1$ \\
\hline
\end{tabular}

\section{Metilfenidat Grubu İçindeki Analizlere Ait Bulgular:}

Metilfenidat tedavisi sonrasında 1. ve 2. değerlendirme arasında ve 2. ve 3. değerlendirme arasında semptom şiddeti (KGi-Ş) skorlarında anlamlı bir azalma ve işlevsellik (GDÖ) skorlarında anlamlı bir artış görülmüștür ( $p<0.01)$. KGI-D ve KGI-YE skorları arasında fark olmamıştır (2-3. Değerlendirmeler).

Başlangıç metilfenidat dozu ile artmış işlevsellik (2. GDÖ skoru) arasında pozitif ilişki bulunmuş ( $p=0.02)$. Klinik düzelme
(2.KGI-D) ile yan etki (KGI-YE) skorlarının arttığı gözlenmiştir $(p=0.02)$. OSB komorbiditesine sahip olanlarda KGi-YE skorları daha yüksek bulunmuş $(p=0.002)$. Metilfenidat dozu ile yan etkiler arasında anlamlı ilişki bulunmamıştır.

Tedaviye yanıt üzerinde etkisi olabileceği düşünülen eşlik eden özellikler olarak yaş, cinsiyet, okul öncesi eğitim alma, prematürite, prenatal-natal-postnatal sorun, tıbbi hastalık etkenlerinin ilaçtan yararlanım ve yan etki ile ilişkisi bulunmamıştır.

Bu grupta yan etki görülen 17 (\%34) hastada en sık ajitasyon ( $n=5)$ görülmüştür ve bu 5 hastada da tedavi kesilmiştir. Görülen yan etkilerin dağlımına dair bilgiler Tablo I'de özetlenmiştir.

\section{Risperidon ve Metilfenidat Gruplarının Karşılaştırılması:}

Çalışma grubumuzda bulunan hastaların kullandıkları ilaçlara göre, kullanan hastaların klinik özellikleri, cinsiyet, yaş, tanı dağılımı Tablo Il'de verilmiştir.

İki grubun sosyodemografik özellikleri karşılaştııılı̆̆ında; cinsiyet değişkeni istatistiksel olarak anlamlı düzeyde farklı bulunmuştur $(p=0.01)$. Her iki grupta da erkek cinsiyetin fazla olduğu ancak risperidon başlanan hasta grubunda kı cinsiyetin metilfenidat başlanan gruba göre daha sık olduğu görülmüştür. Risperidon kullanan grupta yaş ortalaması daha düşüktür $(p<0.01)$. Okul öncesi eğitim metilfenidat kullanan grupta daha sık bulunurken ( $p=0.001$ ), gelişim basamaklarında gecikme öyküsüne daha çok risperidon grubunda rastlanmıştır $(p=0.00)$. Hasta grupları, 
politerapi ve monoterapi şeklinde ilaç kullanmaları açısından da farklılaşmıştır. Metilfenidat grubunda daha yüksek oranda politerapi görülürken $(p<0.01)$, risperidon grubunda daha çok monoterapi kullanıldığı görülmüştür $(p=0.001)$. Bahsedilen analizler Tablo II'de özetlenmiştir.

Metilfenidat ile risperidon grubu arasında KGi-Ş1 skorları arasında fark vardır, risperidon grubunda semptom șiddeti daha yüksektir ( $p=0.003$ ). Yine risperidon grubunda işlevsellik (GDÖ1 skoru) sınırda daha düşüktür ( $p=0.05$ ) (Tablo III).

Her iki ilaç, t-test ile tedaviden sonra düzelen işlevsellik, düzelme skorları, yan etki skorları açısından karşılaştııılığında, iki grup arasında anlamlı bir farkllık saptanmamıştır.

Hastaların ilaç öncesi ve sonrasındaki 2 değerlendirmelerine dair klinik skorları, ilaç dozları Tablo III'de özetlenmiștir.

\section{TARTIŞMA}

Çalışmamızda, okul öncesi çağda kliniğimize başvuran çocuklardan DEHB, OSB, BY tanıları konan hastalar için en sık kullanılan iki ilaç olan risperidon ve metilfenidatın etkinlikleri ve yan etkileri, bu ilaçlardan fayda görmeyi yordayan etkenler, eşlik eden klinik özellikler araştıııımıştır.

Araştırmamızın sonuçlarına göre, risperidonun, yazınla uyumlu olarak okul öncesi dönemde belirti șiddetini azaltma açısından etkili ve yan etki açısından güvenilir olduğu düşünülmüştür (21). Coşkun ve ark.(13) 2011 'de yaptıkları çalışmada risperidon ile hem belirti șiddetinde azalma hem de işlevsellik skorlarında artış saptamıştır. Risperidon dozu ikinci değerlendirmede artııımış $0.75 \mathrm{mg}( \pm 0.6) \mathrm{mg} / \mathrm{gün}$ olmasına rağmen düzelme skorlarında ve yan etki skorlarında anlamlı bir değişiklik olmamıştı. Bu sonuçlar klinisyenlere bu yaş grubu için düşük dozlarda yarar sağlanmıyorsa daha fazla doz artışı ile sonuçların gözlenmesi yerine ajan değişikliği gerekebileceği yönünde bir veri olarak düşünülebilir. Risperidon başlanan grupta sadece 2 olguda enürezis, 1 olguda ise ajitasyon nedeniyle ilacın kesilmesi gerekmiştir. Coşkun ve ark. (13) 2011'de yaptıkları çalışmada enürezisi sık bir yan etki olarak tespit etmişlerdir ve gelişimsel kırılganlı̆̆ı olan olgulara dikkat çekmişlerdir. Yazında da enürezis yan etkisi sıklıkla gelişimsel bozukluğu olan çocuklarda görülen bir yan etki olarak bildirilmiştir $(22,23)$. Kilo alımı, sedasyon gibi belirtiler ise diğer görülen hafif șiddetli, tedaviyi kesmeyi gerektirmeyecek yan etkiler olarak görülmüştür. Bunun dışında, çalışmamızda risperidon grubunda BY olan hasta grubunun işlevselliğinin artmadığı bulunmuştur. Bununla paralel olarak risperidon kullanan çocuklar arasından BY tanısı konulan grupta semptom șiddetinin yüksek olduğu bulunmuştur. BY olan olgularda davranıș sorunları azalsa da aileye bağımllık ve gelişim basamaklarında gecikme devam ettiği için böyle bir ilişki bulunmuş olabilir. Risperidonun DEHB tanısı alan çocuk ve gençlerin, tanı aldıkları yıın devamında en sık reçete edilen antipsikotik olduğu ve 3-5 yaş grubu ek nörogelişimsel bozukluk tanısı alan çocuklarda daha sık kullanıldığı bulunmuştur (24). Nonfarmakolojik tedaviler bu yaş grubunda ilk basamak tedavi olarak önerilse de, çocuk aile etkileşim terapisi, ebeveyn eğitimi gibi seçeneklere ulaşımın kısıtlı olduğu, ayrıca çocukları fiziksel hasardan koruma gibi bazı öncelikler göz önüne alındığında, farmakolojik tedavilerden klinisyenlerin seçim yapmak zorunda kaldığı vurgulanmaktadır (25). Bunlara ek olarak, risperidonun çeşitli formlarının bulunmasından dolayı, bu yaş grubu için kullanım ve titrasyonda kolaylık sağlaması da klinisyenler tarafindan tercih nedeni olmaktadır.

Araştırmamızda, okul öncesi çağda DEHB için önerilen metilfenidat tedavisi sonrasında 1. ve 2. ile 2. ve 3. değerlendirme arasında; semptom şiddeti (KGi-Ş) skorlarında anlamlı bir azalma ve işlevsellik (GDÖ) skorlarında anlamlı bir artış görülmüştür (26). Yazında metilfenidat bașlanan bu yaş grubundaki çocukların 1 ylllık randomize kontrollü izlemleri sonrasında benzer şekilde fayda gördüğü ve ilacın güvenilir bulunduğu belirtilmiştir (27). Ayrıca, çift kör randomize kontrollü bir çalışmada bu yaş grubunda metilfenidat tedavisinin, aile çocuk etkileşim terapisinden daha etkili olduğu, tedaviye devamın yüksek oranda sağlanabildiği bildirilmiştir (28). Aile çocuk etkileşim terapisi, araştırmalara dahil olmak için onam veren ve tam olarak hasta populasyonunun ailelerini yansıtmayacak kadar uyumlu gözüken aileler de bile $\% 51$ tedaviyi bırakma oranına sahiptir (29). Kısa etkili metilfenidat ile gün içinde zaman ayarlaması yapılabilmesi de bu yaş grubu için avantaj oluşturmaktadır. Bununla birlikte, uzun etkili metilfenidatların da bu yaş grubunda iyi tolere edildiği ve faydalı olduğu gösterilmiştir (30). Metilfenidat dozunda görülen değişikliklere rağmen (genel olarak artış yönünde) düzelme ve yan etki skorlarında 2. ve 3. değerlendirmeler arasında anlamlı bir fark olmamıştır. Bu da etkin doza ulaşıldıktan sonra doz artışının gerekmeyeceği şeklinde yorumlanabilir. Çalışmamızda başlangıç metilfenidat dozu arttıkça işlevselliğin arttığı bulunmuştur. Bu sonuçlar etkin dozda metilfenidat kullanımının daha iyi sonuçlar ile ilișkili olabileceğini düşündürmüștür. Araștırmamızda, metilfenidat grubunda klinik düzelme arttıkça, yan etkinin artıı̆ı gözlenmiștir. Bu bulgu bize doz artışları sırasında yan etkinin iyi sorgulanması gerektiğini bir kez daha göstermiștir. Ayrıca metilfenidat grubumuzda, OSB komorbiditesine sahip olanlarda yan etki oranları yazınla uyumlu şekilde daha yüksek bulunmuştur (31). Ancak yakın zamanlı bir metaanaliz sonucunda, OSB komorbiditesinde kullanılan metilfenidat ile yan etkilerin fazla görüldügüne dair bir bulgu saptanmamıştır (32).

Tedaviye yanıt üzerinde etkisi olabileceği düşünülen eşlik eden özellikler olarak yaş, cinsiyet, okul öncesi eğitim alma, prematürite, prenatal-natal-postnatal sorun, tıbbi hastalığın ilaçtan yararlanım ve yan etki ile ilişkisi her iki grupta da bulunmamıştır. Bunun da araştırma grubumuzun küçüklügü ve araştırma grubuna seçim kriterlerimiz ile ilişkili olabileceği düşünülmüştür.

Metilfenidat ve risperidon kullanan hasta grupları birbiri ile kıyaslandığında; risperidon kullanan grupta sosyodemografik 
değişkenlerden kız cinsiyet ağırlığı ve yaş ortalaması düşüklüğü göze çarpmıştır. Ayrıca bu grupta semptom şiddeti (KGi-Ş skorları) daha yüksek olmasına rağmen, daha çok monoterapi kullanımış olup, okul öncesi eğitime katılma oranı daha düşük, gelișim basamaklarında gecikme öyküsü, OSB ve BY tanısı da daha sık görülmektedir. Bu verilere bakılarak, kliniğimizde daha düşük ișlevselliğe sahip ağır nörogelișimsel bozukluğu olan olgularda, kullanım kolaylığı ve irritabilite üzerindeki etkisi de göz önüne alınarak, davranışsal müdahelelere uyumun zayıf olacağı düşünülen okul öncesi çağdaki hastalar için farmakolojik tedavilerden öncelikle risperidon tercih edildiği söylenebilir.

Araştırmamızın güçlü yanları; okul öncesi yaş grubunda her iki ilacın kullanımına ilişkin geniş sayılabilecek bir örnekleme ulașıması, ilaçtan yararlanıma ilişkin değerlendirmenin klinisyenlerce iki farklı araç skorlaması ile yapılması ve işlevsellik değerlendirmesini de içermesidir. Araştırmamızın zayıf yanları ise klinik skorlamanın retrospektif olarak hasta kayitlarından yapılması, araştırmaya tedaviye devam etmeyen hastaların dahil edilmemesi nedeniyle tedaviye bașlanan tüm hastalarla ilgili sonuca ulaşılamamış olması ve tedavi üzerine etkisi olabilecek tüm değişkenlerin notlarda kayıtlı olmadığı için değerlendirilememesidir. Ayrıca hastaların metabolik parametrelerine dair biyolojik belirteçler de kullanılmamıştır ve hastaların sadece 6 ayllk tedavi izlemleri değerlendirmelere girebilmiștir. Bununla beraber, hasta değerlendirmesinde okul öncesi çağ için tanısal standart bir araç kullanılmadığı da akılda bulunmalıdır.

Bu yaş grubu için tedavi planlarken klinisyenlerin psikofarmakolojik tedavi seçmesi gerektiğinde, bu ilaçlarla ilgili klinik bilgi birikiminin yol gösterici olması gerekmektedir. Bu nedenle bu yaş grubu için yapılacak uzunlamasına, sadece ilaç etki ve yan etkilerinin değil, yanıtla ilişkilendirilebilecek biyolojik belirteçlerinde değerlendirilebileceği ilaç çalışmalarına intiyaç vardır.

\section{KAYNAKLAR}

1. Arabgol F, Panaghi L, Nikzad V. Risperidone Versus Methylphenidate in Treatment of Preschool Children With Attention-Deficit Hyperactivity Disorder. Iran J Pediatr 2015; 25:e265

2. Tandon M, Si X, Luby J. Preschool onset attention-deficit/ hyperactivity disorder: course and predictors of stability over 24 months. J Child Adolesc Psychopharmacol 2011; 21:321-30.

3. Uygun SD GZ, Acikel SB, Dinc G, Hekim O, Cop E, Uneri OS. Psychotropic Drug Use in Preschool and Toddler Age Groups: An Evaluation of Hospital Admissions. Psychiatry and Behavioral Sciences 2019; 9:112-8.

4. Egger HL, Angold A. Common emotional and behavioral disorders in preschool children: presentation, nosology, and epidemiology. J Child Psychol Psychiatry 2006; 47:313-37.

5. Wichstrom L, Berg-Nielsen TS, Angold A, Egger HL, Solheim E, Sveen TH. Prevalence of psychiatric disorders in preschoolers. J Child Psychol Psychiatry 2012; 53:695-705.
6. Fanton J, Gleason MM. Psychopharmacology and preschoolers: a critical review of current conditions. Child Adolesc Psychiatr Clin N Am 2009; 18:753-71.

7. Taş FV ÖA, Janbakhishov CE, Karaarslan D. . Bir üniversite kliniği deneyimi: erken çocukluk döneminde psikotrop ilaç kullanımı. Çocuk ve Gençlik Ruh Sağlığı Dergisi 2015; 22: 17-27.

8. Connor DF. Preschool attention deficit hyperactivity disorder: a review of prevalence, diagnosis, neurobiology, and stimulant treatment. J Dev Behav Pediatr 2002; 23:S1-9.

9. Boyle CA, Boulet S, Schieve LA, Cohen RA, Blumberg SJ, YearginAllsopp $\mathrm{M}$, et al. Trends in the prevalence of developmental disabilities in US children, 1997-2008. Pediatrics 2011; 127:103442.

10. Gleason MM, Egger HL, Emslie GJ, Greenhill LL, Kowatch RA, Lieberman AF, et al. Psychopharmacological treatment for very young children: contexts and guidelines. J Am Acad Child Adolesc Psychiatry 2007; 46:1532-72.

11. Spetie L, Arnold LE: Attention-Deficit/Hyperactivity Disorder; in: Andres M, Volkmar FR (eds): Lewis's Child and Adolescent Psychiatry: A Comprehensive Textbook 4th Edition. USA Lippincott Williams \& Wilkins 2007, pp 431-54.

12. Safavi P, Dehkordi AH, Ghasemi N. Comparison of the effects of methylphenidate and the combination of methylphenidate and risperidone in preschool children with attention-deficit hyperactivity disorder. J Adv Pharm Technol Res 2016; 7:144-8.

13. Coskun M ZSS, Ozturk M. Risperidone Treatment in Preschool Children with Disruptive Behavior Disorders: A Chart Review Study. Klinik Psikofarmakoloji Bülteni 2011;21:1, 33-4.

14. Fuentes-Biggi J, Ferrari-Arroyo MJ, Boada-Munoz L, TourinoAguilera E, Artigas-Pallares J, Belinchon-Carmona M, et al. [Good practice guidelines for the treatment of autistic spectrum disorders]. Rev Neurol 2006; 43:425-38.

15. Fung LK, Mahajan R, Nozzolillo A, Bernal P, Krasner A, Jo B, et al. Pharmacologic Treatment of Severe Irritability and Problem Behaviors in Autism: A Systematic Review and Meta-analysis. Pediatrics 2016; 137 Suppl 2:S124-35.

16. Masi G, Cosenza A, Mucci M, De Vito G. Risperidone monotherapy in preschool children with pervasive developmental disorders. J Child Neurol 2001;16:395-400.

17. Hollingshead AB, Redlich FC. Social class and mental illness: a community study. 1958. Am J Public Health 2007; 97:1756-7.

18. GuyW, editor. ECDEUAssessmentManualforPsychopharmacology. Rockville, MD: US Department of Heath, Education, and Welfare Public Health Service Alcohol, Drug Abuse, and Mental Health Administration 1976:76-338.

19. Busner J, Targum SD. The clinical global impressions scale: applying a research tool in clinical practice. Psychiatry (Edgmont) 2007; 4:28-37.

20. Endicott J, Spitzer RL, Fleiss JL, Cohen J. The global assessment scale. A procedure for measuring overall severity of psychiatric disturbance. Arch Gen Psychiatry 1976; 33:766-71.

21. Aman MG. Treatment of Severe Childhood Aggression (TOSCA) Studies. J Child Adolesc Psychopharmacol 2015; 25:201-2.

22. Aman MG, Arnold LE, McDougle CJ, Vitiello B, Scahill L, Davies $\mathrm{M}$, et al. Acute and long-term safety and tolerability of risperidone in children with autism. J Child Adolesc Psychopharmacol 2005; 15:869-84

23. Herguner S, Mukaddes NM. Risperidone-induced enuresis in two children with autistic disorder. J Child Adolesc Psychopharmacol 2007; 17:527-30. 
24. Sultan RS, Wang S, Crystal S, Olfson M. Antipsychotic Treatment Among Youths With Attention-Deficit/Hyperactivity Disorder. JAMA Netw Open 2019; 2:e197850.

25. Chung J, Tchaconas A, Meryash D, Adesman A. Treatment of Attention-Deficit/Hyperactivity Disorder in Preschool-Age Children: Child and Adolescent Psychiatrists' Adherence to Clinical Practice Guidelines. J Child Adolesc Psychopharmacol 2016; 26:335-43.

26. Greenhill L, Kollins S, Abikoff H, McCracken J, Riddle M, Swanson $\mathrm{J}$, et al. Efficacy and safety of immediate-release methylphenidate treatment for preschoolers with ADHD. J Am Acad Child Adolesc Psychiatry 2006; 45:1284-93.

27. Wigal T, Greenhill L, Chuang S, Mc GJ, Vitiello B, Skrobala A, et al. Safety and tolerability of methylphenidate in preschool children with ADHD. J Am Acad Child Adolesc Psychiatry 2006; 45:1294-303.

28. van der Veen-Mulders L, van den Hoofdakker BJ, Nauta $M H$, Emmelkamp P, Hoekstra PJ. Methylphenidate Has Superior Efficacy Over Parent-Child Interaction Therapy for Preschool Children with
Disruptive Behaviors. J Child Adolesc Psychopharmacol 2018; 28:66-73.

29. Hoekstra PJ. Looking beyond randomized controlled trials. Eur Child Adolesc Psychiatry 2017; 26:385-6.

30. Adjei AL, Chaudhary I, Kollins SH, Padilla A. A Pharmacokinetic Study of Methylphenidate Hydrochloride Multilayer ExtendedRelease Capsules (Aptensio XR((R))) in Preschool-Aged Children with Attention-Deficit/Hyperactivity Disorder. Paediatr Drugs 2020; 22:561-70.

31. Handen BL, Feldman HM, Lurier A, Murray PJ. Efficacy of methylphenidate among preschool children with developmental disabilities and ADHD. J Am Acad Child Adolesc Psychiatry 1999; 38:805-12.

32. Sturman N, Deckx L, van Driel ML. Methylphenidate for children and adolescents with autism spectrum disorder. Cochrane Database Syst Rev 2017; 11:CD011144. 